\title{
Processing of microbial biomass by an intertidal reef community*
}

\author{
Thomas H. Chrzanowski ${ }^{1}$, John D. Spurrier ${ }^{2}$, Richard F. Dame ${ }^{3}$, \& R. G. Zingmark ${ }^{4}$ \\ ${ }^{1}$ Department of Biology, The University of Texas at Arlington, Arlington, Texas 76019, USA \\ ${ }^{2}$ Department of Statistics and Belle W. Baruch Institute for Marine Biology and Coastal Research, University of South Carolina, \\ Columbia, South Carolina 29208, USA \\ ${ }^{3}$ Department of Marine Science and Belle W. Baruch Institute for Marine Biology and Coastal Research, University of South \\ Carolina, Conway, South Carolina 29526, USA \\ ${ }^{4}$ Department of Biology and Belle W. Baruch Institute for Marine Biology and Coastal Research, University of South Carolina, \\ Columbia, South Carolina 29208, USA
}

\begin{abstract}
Intertidal reef communities dominated by filter feeding organisms (such as the American oyster Crassostrea virginica) are a prominent feature of some marsh-estuarine systems of the southeastem United States. Such reef communities may be considered as major components in the coupling of aquatic and benthic systems within the marsh. The ability of the reef community to remove suspended microbial biomass (as ATP) was investigated through the use of a $10 \mathrm{~m}$ long plexiglas tunnel that covered $7.9 \mathrm{~m}^{2}$ of reef surface. Generally, there was a net loss of suspended microbial biomass as water flowed over the reef. Microbial biomass levels were lower at the output from the tunnel than at the input to the tunnel for $61 \%$ of flood tides and $76 \%$ of ebb tides. Determinations of net transport revealed that total microbial biomass was imported to the reef on 26 of 33 flood-tide phases and 27 of 33 ebb-tide phases. Import rates ranged between 0.11 and $5.39 \mu \mathrm{g} \mathrm{ATP} \mathrm{s}{ }^{-1}$ during flood tides and between 0.46 and $18.20 \mu \mathrm{g} \mathrm{ATP} \mathrm{s}^{-1}$ during ebb tides. Annually $55 \mathrm{~g}$ ATP were imported to the reef community. This import rate corresponded to an equivalent carbon flow of $1750 \mathrm{~g} \mathrm{C} \mathrm{m}^{-2} \mathrm{yr}^{-1}$ The net flow of microbial carbon into the reef community was 20 times greater than reported estimates of particulate organic carbon flow from the entire marsh system to the ocean.
\end{abstract}

\section{INTRODUCTION}

Salt marshes of the southeastern United States are highly productive ecosystems in which the net primary production is processed within or moved via tidal waters to neighboring habitats. The movement of suspended materials via tidal water has been the subject of numerous investigations (see Nixon 1981 for review). For the most part, studies have sought to determine rates of material exchange between marshes and bordering estuaries or oceans. Implicit in such studies is the assumption that net material movement reflects the cumulative result of biological and physical processes occurring within the marsh system. As a result, marsh systems are typically 'black-boxed' with the contribution of various marsh zones (as Spartina grasslands, mudflats, or reef communities) to the

- Contribution No. 616 of the Belle W. Baruch Library in Marine Science net material transport inferred from nutrient processing studies (see Riemold 1972 for example).

A prominent feature of some salt marsh systems along the southeastern United States is the presence of expansive intertidal reef communities. The reefs are dominated by the American oyster Crassostrea virginica whose density may be as high as 4077 ind $\mathrm{m}^{-2}$ (Dame et al. 1984). The high density of oysters, physical structure of the reef, and biological activity of the attendant community have prompted speculation concerning the role of these reef communities in the overall material transport process.

Dame et al. (1980) reviewed much of the literature dealing with the ability of estuarine filter feeder reef communities to influence or alter the overlying water column. They concluded that the benthic filter feeding organisms within salt marshes are capable of influencing the levels of suspended particulate matter and suggested that filter feeders are a major component in the coupling between benthic and aquatic systems. In 
a subsequent paper, Dame et al. (1984) demonstrated coupling of benthic and aquatic systems by showing that an intertidal reef community removed particulate organic carbon from water passing over the reef while enriching the water with ammonia.

Microflora are a major component of the suspended particulate matter in salt marsh systems and generally considered as part of the principal food source of filter feeders (McHenery \& Birkbeck 1985). Organisms commonly found in intertidal reef communities such as Guekensia demissa, Mytilus edulis, and Mya arenaria have been shown to effectively remove bacteria and bacterial sized particles from water (Birkbeck \& McHenery 1982). Wright et al. (1982) recently demonstrated that $G$. demissa could effectively remove suspended bacterioplankton and that $M$. edulis could reduce the concentration of chlorophyll in water passing a Mytilus dominated reef community.

It seems reasonable to speculate that intertidal reef communities may constitute a defined zone within a marsh where the concentration of suspended microbial biomass could be altered. Functionally, material processing by reef communties may contribute to an overall model describing net transport of microbial biomass through salt marsh systems. This study addresses the net directional transport of microbial biomass as tidal waters flow over an intertidal reef community.

\section{MATERIALS AND METHODS}

Sampling took place within a defined tidal basin, Bly Creek basin (Fig. 1), of the North Inlet marshestuarine ecosystem $\left(33^{\circ} 20^{\prime} \mathrm{N}, 79^{\circ} 10^{\prime} \mathrm{W}\right)$. Stratigraphic and geomorphic features of the basin have been previously described (Gardner \& Bohn 1980). A systematic sampling design was used in which samples were collected approximately every $11 \mathrm{~d}$ between June 1983 and June 1984. Samples were collected during both day and night conditions from a $10 \mathrm{~m}$ long, dome-shaped plexiglas tunnel (Benthic Ecosystem Tunnel, BEST, Fig. 2) installed over $7.9 \mathrm{~m}^{2}$ of midintertidal zone oyster reef community. The reef community covered approximately $250 \mathrm{~m}^{2}$ and had an oyster density of 2000 to 4500 ind $\mathrm{m}^{-2}$ (depending upon season). Community composition of oyster reefs in North Inlet has been previously described (Dame 1976 , 1979).

The BEST was designed so that sections could be installed as tide height increased. Sections were joined with neoprene gaskets and a 'skirt gasket' was fitted to the sediment to minimize lateral water flow beneath the tunnel edges. Discrete water samples were pumped (Guzzler pump) simultaneously from $0.5 \mathrm{~m}$ inside each end of the BEST 12 times during the period that the tunnel was completely submerged. The pump inlet tubing extended $15 \mathrm{~cm}$ inside the tunnel. An effort was made to distribute sampling intervals equally over flood and ebb tide phases. Water was collected in sterile, acid-washed, $500 \mathrm{ml}$ glass bottles and rapidly transported in iced coolers to nearby laboratory facilities. Water velocity through the tunnel was measured with a Marsh-McBirney current meter positioned in the center of the tunnel. Positioning the current meter in the BEST center yielded velocity data that were representative of flow through the entire tunnel (Kjerfve, unpubl. data).

Total microbial biomass was measured as adenosine triphosphate (ATP) (Stevenson et al. 1979, Chrzanowski et al. 1981, Stevenson et al. 1981). Sub-samples $(20 \mathrm{ml})$ were filtered onto $25 \mathrm{~mm}$ glass-fiber filters (Whatman GF/F) and ATP was extracted in boiling Tris buffer (Holm-Hansen 1973, Holm-Hansen \& Booth 1966). Extractions were done in triplicate and assayed by the luciferin-luciferase technique coupled to an SAI
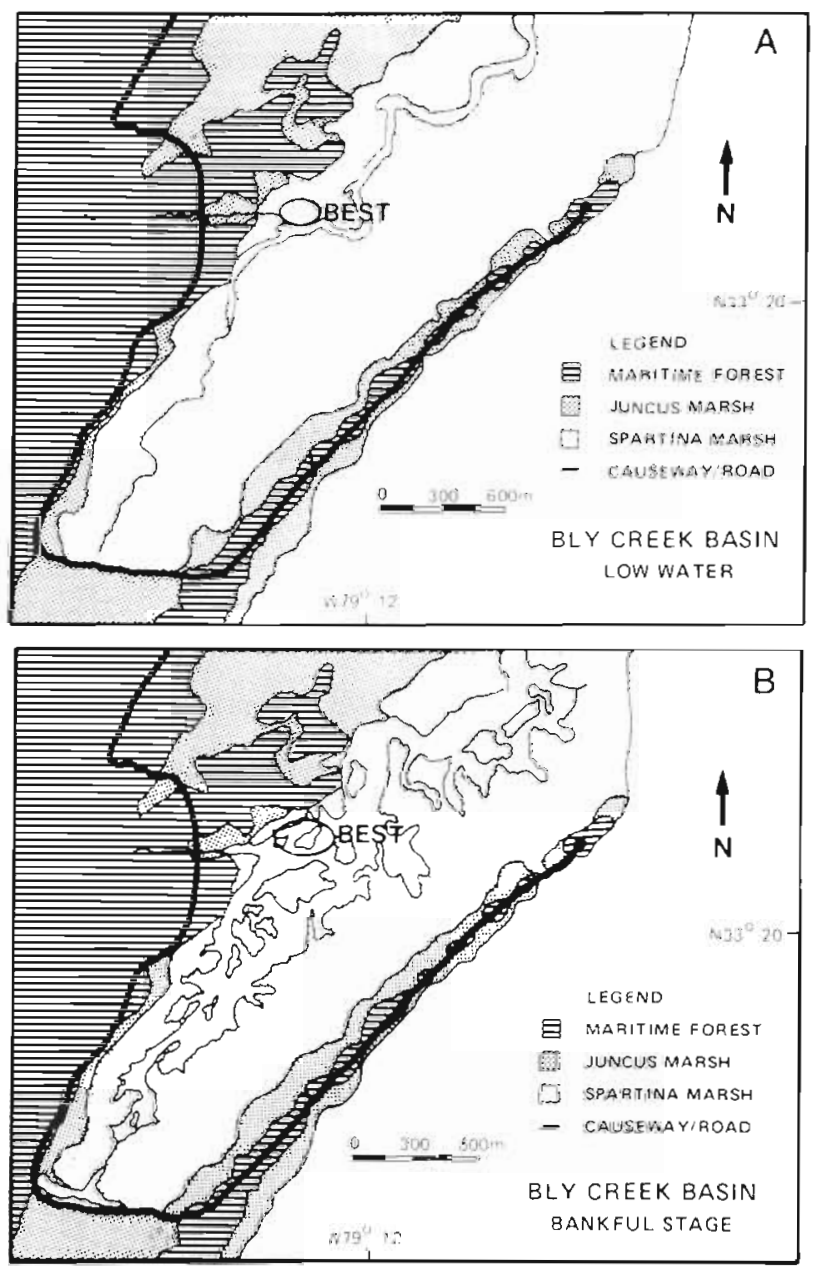

Fig. 1. Diagram of the Bly Creek basin, North Inlet Estuary, South Carolina, USA, showing the approximate position of the reef community: (A) basin at low tide, $(B)$ at bankful stage 
and full tunnel submergence. Similarly, net ebb tide transport was determined by averaging the 6 instantaneous transport estimates and multiplying by $(C+0.5 D)$, where $C$ was the length of time that the tunnel was submerged and D was the time between when the tunnel was last fully submerged and all water left the tunnel.

Calculation of annual budgets. There were a total of 707 tidal cycles during the sampling period. Net transport was estimated for a systematic sample of 33 of the population of 707 cycles (see opening paragraph of 'Materials and Methods'). In addition, a set of 38 potential predictor variables were measured for each of the 707 total cycles (Table 1). Stepwise regression analysis was performed to select a smaller set of predictor variables used to model the net flux over a tidal cycle. The subset of predictor variables was further refined by running all possible regressions and selecting the model that produced the minimum value of Mallows' (1973) Cp statistic. This model was used to form a regression estimate of net monthly and annual transports (Cochran 1977, Chapter 7). The standard error associated with the annual net flux estimate took into account cycle to cycle variability in net tidal cycle flux as well as error in estimating actual net flux for the 33 sampled cycles. Statistical analyses were carried out using the SAS statistical program package (1985).

\section{RESULTS AND DISCUSSION}

North Inlet experiences semi-diurnal tides with distinct velocity asymmetry (ebb velocity $>$ flood velocity). The tidal range is approximately $2 \mathrm{~m}$ and the water column is well mixed as a result of turbulent flow. Under these conditions, a net change in concentration of any suspended variable flowing over the benthic community of a reef will be detectable only if there is sufficient biological (and physical) action on the reef to effect the entire water column above the reef. It is more difficult to detect concentration changes as both the water depth and water velocity increase. The BEST circumvented these difficulties by minimizing advective flow (essentially 'parcelling' water) and maintaining reasonably constant conditions of reef surface area covered (with some annual increase due to shell growth), volume of water within, and sampling height above bottom.

Examples of changes in microbial biomass as water flowed through the BEST are shown in upper panels of Fig. 3 and 4 . There were no consistent tidally-induced fluctuations in ATP levels. Occasionally, ATP fluctuated out-of-phase with tidal rhythms (Fig. $4 a$, b, flood tide input, ebb tide output) as was reported for other sites within North Inlet (Erkenbrecher \& Stevenson

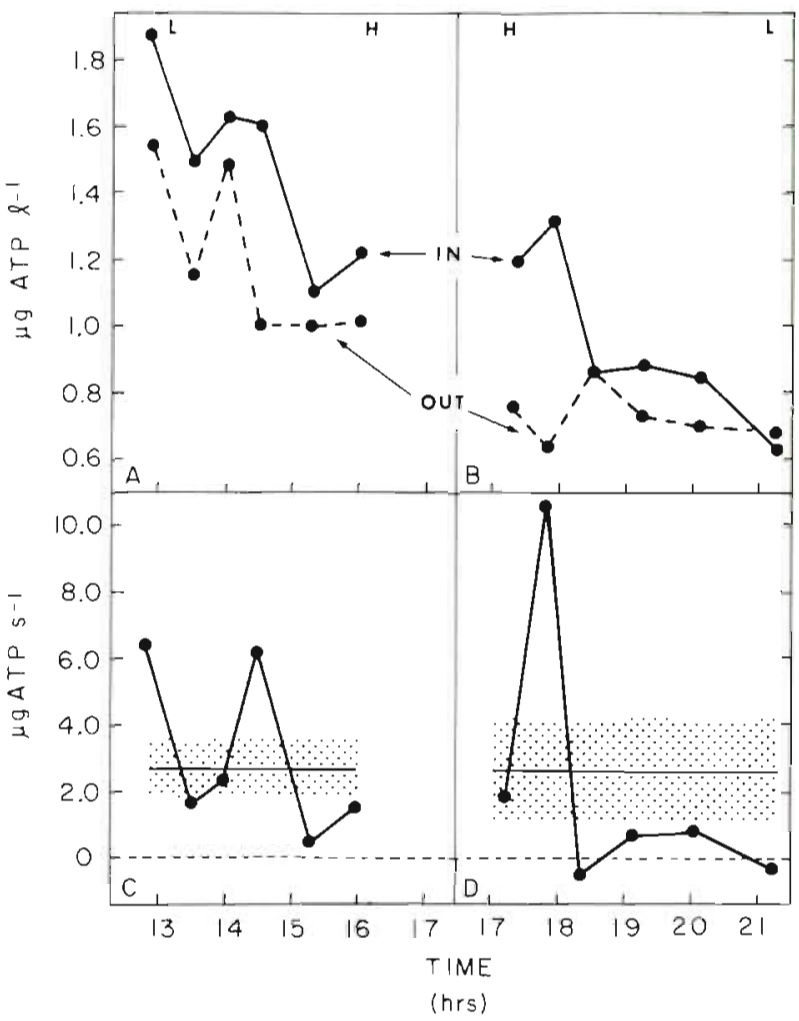

Fig. 3. (A, B) Fluctuations of ATP levels at input (IN) and output (OUT) ends of the BEST and $(C, D)$ resultant instantaneous net transports, for a spring tide in September. (A, C) Flood tide phase; $(B, D)$ ebb tide phase $(\mathrm{L}=$ low tide, $\mathrm{H}=$ high tide). Stippled areas in lower panels represent the standard error of the average net transport (solid bar through stippled area). Time axis shown as hours on a $24 \mathrm{~h}$ clock

1975, Chrzanowski et al. 1981, 1982a). There was a net loss of suspended microbial biomass as water flowed over the reef (compare input to output concentrations in Fig. 3 and 4). When the average of input values were compared to the average of output values, microbial biomass levels were lower at the outputs than at the inputs of $61 \%$ of flood tides and $76 \%$ of ebb tides (Table 2). However, as might be expected from a turbulent system, there was considerable variability around the averages with flood data showing greater variability than ebb tide data (Table 2). Consequently, the difference between average ATP levels at input and output ends of the BEST was statistically significant on 11 of 33 cycles (Table 1, $\alpha<0.10$, paired t-test) with $73 \%$ indicating a concentration loss. During ebb tide phases, 17 of 33 cycles had a significant loss of microbial biomass as water flowed over the reef.

It is apparent that microbial biomass was removed from the water more frequently during ebb tides than during flood tides. Additional losses of microbial biomass during ebb tides may have occurred but were not detected. It would be more difficult to detect a loss 


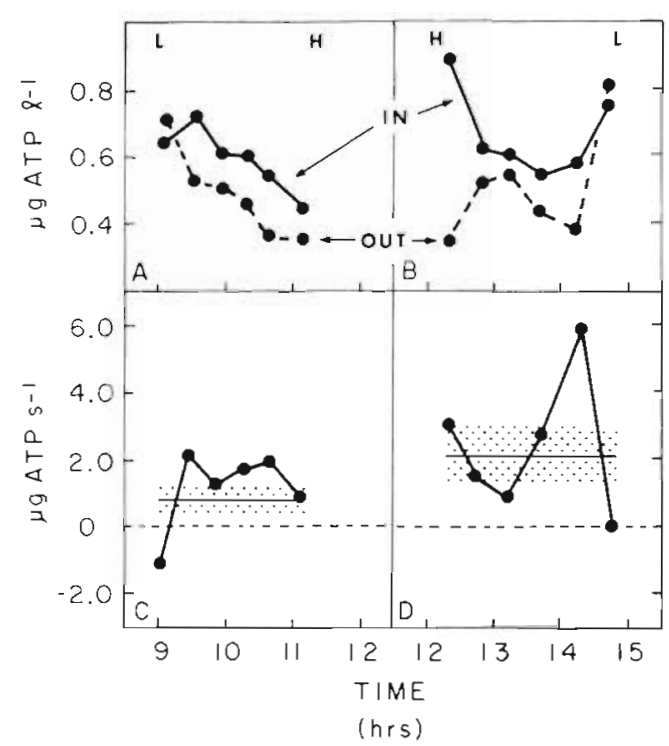

Fig. 4. (A, B) Fluctuations of ATP levels at input (IN) and output (OUT) ends of the BEST and (C, D) resultant instantaneous net transports, for a mid-tide in January. (A, C) Flood tide phase; $(B, D)$ ebb tide phase $(\mathrm{L}=$ low tide, $\mathrm{H}=$ high tide). Stippled areas in lower panels represent the standard error of the average net transport (solid bar through stippled area). Time axis shown as hours on a $24 \mathrm{~h}$ clock

of material during ebb tides than during flood tides since ebb tide water velocities are greater than flood tide velocities. Greater ebb tide velocities would also permit increased rates of resuspension and it is conceivable that higher concentrations of microbial biomass entered the BEST during ebb tides. To test this, input concentrations on flood tides were compared to the input concentrations on ebb tides. Input concentrations on flood and ebb tides were significantly different ( $\alpha<0.05$, t-test) on 6 of the 33 tide cycles. On only 3 of the 6 cycles where differences were found, were the ebb input concentrations higher than flood input concentrations. Thus, higher concentrations of microbial biomass did not enter the BEST during ebbing tides. It is likely that ebbing tidal water contains a different suspended microbial assemblage than does flooding water and that this assemblage is more susceptible to removal by the reef community (Wilson et al. 1981, Chrzanowski et al. 1982a, Chrzanowski \& Zingmark 1986).

\section{Mass transport}

Examples of instantaneous mass transport of microbial biomass are shown in the lower panels of Fig. 3 and 4 . Instantaneous transport rates typically ranged between 0.2 and $10.0 \mu \mathrm{g} \mathrm{ATP} \mathrm{s}{ }^{-1}$ with values erratically distributed over a tide phase (flood or ebb). Erratic transport patterns were the result of variable con-
Table 2. Net change in ATP concentrations between input and output ends of the BEST. Positive values indicate a gain by the reef, negative values indicate a loss from the reef. Each value is the mean of 6 measurements

\begin{tabular}{|c|c|c|c|}
\hline \multirow[t]{2}{*}{$\begin{array}{l}\text { Date } \\
(1983-1984)\end{array}$} & \multirow[t]{2}{*}{$\begin{array}{l}\text { Tide high } \\
\qquad(\mathrm{cm})\end{array}$} & \multicolumn{2}{|c|}{$\begin{array}{c}\text { Net concentration difference } \\
\left(\mu \mathrm{g} A T P l^{-1} \pm S E\right)\end{array}$} \\
\hline & & Flood phase & Ebb phase \\
\hline 20 Jun & 94 & $0.29 \pm 0.07^{\cdots}$ & $-0.01 \pm 0.21$ \\
\hline 30 & 86 & $0.26 \pm 0.13$ & $0.26 \pm 0.09 \cdots$ \\
\hline $12 \mathrm{Jul}$ & 120 & $0.00 \pm 0.05$ & $-0.10 \pm 0.47$ \\
\hline 23 & 50 & $0.23 \pm 0.04 \cdots$ & $0.24 \pm 0.07 \cdots$ \\
\hline 02 Aug & 49 & $-0.10 \pm 0.12$ & $0.16 \pm 0.15$ \\
\hline 13 & 90 & $-0.10 \pm 0.36$ & $0.45 \pm 0.11 \cdots$ \\
\hline 25 & 82 & $-0.14 \pm 1.53$ & $0.46 \pm 0.19^{\circ}$ \\
\hline 04 Sep & 106 & $0.07 \pm 0.20$ & $0.19 \pm 0.14$ \\
\hline 15 & 108 & $-0.24 \pm 0.08 \cdots$ & $0.22 \pm 0.11$ \\
\hline 25 & 90 & $-0.37 \pm 0.33$ & $0.21 \pm 0.07^{\cdots}$ \\
\hline 07 Oct & 122 & $0.08 \pm 0.29$ & $0.14 \pm 0.05^{\cdots}$ \\
\hline 18 & 75 & $-0.17 \pm 0.07^{\circ}$ & $0.09 \pm 0.10$ \\
\hline 28 & 51 & $-0.06 \pm 0.03^{\circ}$ & $-0.03 \pm 0.07$ \\
\hline 09 Nov & 118 & $0.01 \pm 0.16$ & $0.23 \pm 0.10^{\bullet}$ \\
\hline 20 & 104 & $0.27 \pm 0.18$ & $0.07 \pm 0.04^{\circ}$ \\
\hline 30 & 74 & $0.15 \pm 0.05^{\cdots}$ & $0.06 \pm 0.06$ \\
\hline $11 \mathrm{Dec}$ & 66 & $0.03 \pm 0.05$ & $0.10 \pm 0.04^{\bullet}$ \\
\hline 21 & 115 & $-0.03 \pm 0.07$ & $-0.02 \pm 0.02$ \\
\hline $08 \mathrm{Jan}$ & 79 & $0.10 \pm 0.04^{\bullet}$ & $0.16 \pm 0.73^{\circ}$ \\
\hline 18 & 86 & $0.03 \pm 0.06$ & $-0.01 \pm 0.01$ \\
\hline 29 & 41 & $0.35 \pm 0.10^{\cdots}$ & $0.15 \pm 0.06^{\circ}$ \\
\hline 20 Feb & 93 & $0.10 \pm 0.04^{\circ}$ & $-0.04 \pm 0.04$ \\
\hline $02 \mathrm{Mar}$ & 70 & $0.09 \pm 0.07$ & $-0.04 \pm 0.06$ \\
\hline 12 & 103 & $0.07 \pm 0.05$ & $0.01 \pm 0.05$ \\
\hline 23 & 47 & $0.22 \pm 0.19$ & $0.31 \pm 0.06^{\cdots}$ \\
\hline $04 \mathrm{Apr}$ & 78 & $-0.01 \pm 0.02$ & $0.14 \pm 0.07$ \\
\hline 14 & 121 & $0.14 \pm 0.06^{\circ}$ & $-0.01 \pm 0.09$ \\
\hline 25 & 54 & $-0.01 \pm 0.22$ & $0.36 \pm 0.18$ \\
\hline 05 May & 82 & $0.54 \pm 0.56$ & $0.58 \pm 0.16^{\circ}$ \\
\hline 17 & 116 & $0.17 \pm 0.16$ & $0.46 \pm 0.17^{\cdots}$ \\
\hline 28 & 64 & $0.15 \pm 0.07^{\circ}$ & $0.27 \pm 0.07^{\cdots}$ \\
\hline 08 Jun & 77 & $-0.11 \pm 0.08$ & $0.38 \pm 0.10^{\circ}$ \\
\hline 19 & 55 & $-0.19 \pm 0.24$ & $0.74 \pm 0.24 \cdots$ \\
\hline $\begin{aligned} & =\text { significa } \\
\cdots & =\text { significa }\end{aligned}$ & $\begin{array}{l}\text { ance at } \alpha< \\
\text { ance at } \alpha<\end{array}$ & $\begin{array}{l}0.1 \\
0.05\end{array}$ & \\
\hline
\end{tabular}

centration differences between input and output ends of the BEST (compare concentration data of Fig. 3B to transport data in Fig. 3D). Highly erratic transport patterns are in distinct contrast to the rhythmic dischargelike patterns reported by Chrzanowski et al. (1982a) for marsh-ocean interfaces. Despite an overall erratic pattern, individual data points typically indicated an import to the reef. Exports from the reef were sporadic and almost always isolated events (Fig. 4C).

Average net instantaneous transports during flood and ebb tide phases are summarized in Table 3. Total microbial biomass was imported to (taken up by) the reef on 26 of 33 flood tide phases and net transport rates ranged from 0.11 to $5.39 \mu \mathrm{g} \mathrm{ATP} \mathrm{s}^{-1}$. Of the periods indicating an import, $35 \%$ could be statisti- 
Table 3. Net transport of ATP through the BEST Positive values indicate an import to the reef, negative values indicate an export from the reef. Each value is the mean of 6 measurements

\begin{tabular}{|c|c|c|c|}
\hline \multirow[t]{2}{*}{$\begin{array}{l}\text { Date } \\
(1983-1984)\end{array}$} & \multirow[t]{2}{*}{$\begin{array}{l}\text { Tide high } \\
\text { (cm) }\end{array}$} & \multicolumn{2}{|c|}{$\begin{array}{l}\text { Net ATP transport } \\
\left(\mu \mathrm{g} \text { ATP } s^{-1} \pm S E\right)\end{array}$} \\
\hline & & Flood phase & Ebb phase \\
\hline $20 \mathrm{Jun}$ & 94 & $3.25 \pm 0.93^{\cdots}$ & $1.18 \pm 4.12$ \\
\hline 30 & 86 & $2.96 \pm 1.42^{\circ}$ & $4.04 \pm 1.83^{\circ}$ \\
\hline $12 \mathrm{Jul}$ & 120 & $-0.02 \pm 0.78$ & $-1.13 \pm 0.11$ \\
\hline 23 & 50 & $1.77 \pm 0.80$ & $3.50 \pm 1.09 \cdots$ \\
\hline 02 Aug & 49 & $0.21 \pm 0.88$ & $2.15 \pm 2.46$ \\
\hline 13 & 90 & $0.42 \pm 4.52$ & $7.89 \pm 2.89^{\circ}$ \\
\hline 25 & 82 & $2.52 \pm 5.66$ & $10.60 \pm 5.20^{\circ}$ \\
\hline 04 Sep & 106 & $-0.17 \pm 3.18$ & $7.68 \pm 4.80$ \\
\hline 15 & 108 & $2.73 \pm 0.90^{\circ}$ & $2.65 \pm 1.63$ \\
\hline 25 & 90 & $4.24 \pm 3.73$ & $4.25 \pm 1.41^{\cdots}$ \\
\hline $07 \mathrm{Oct}$ & 122 & $-0.15 \pm 2.77$ & $3.21 \pm 1.44^{\circ}$ \\
\hline 18 & 75 & $1.54 \pm 0.62^{\circ}$ & $0.68 \pm 1.25$ \\
\hline 28 & 51 & $0.23 \pm 0.10^{\circ}$ & $-1.18 \pm 0.91$ \\
\hline 09 Nov & 118 & $0.76 \pm 0.66$ & $3.93 \pm 1.32 \cdots$ \\
\hline 20 & 104 & $1.86 \pm 1.05$ & $1.22 \pm 0.53^{\circ}$ \\
\hline 30 & 74 & $1.41 \pm 0.53^{\cdots}$ & $1.02 \pm 1.78$ \\
\hline $11 \mathrm{Dec}$ & 66 & $0.17 \pm 0.41$ & $1.50 \pm 0.62^{\circ}$ \\
\hline 21 & 115 & $-0.20 \pm 1.01$ & $-0.36 \pm 0.62$ \\
\hline $08 \mathrm{Jan}$ & 79 & $0.89 \pm 0.43^{\circ}$ & $2.10 \pm 0.77^{\cdots}$ \\
\hline 18 & 86 & $0.26 \pm 0.79$ & $-0.50 \pm 1.06$ \\
\hline 29 & 41 & $2.39 \pm 0.64 \cdots$ & $1.78 \pm 0.86^{\circ}$ \\
\hline $20 \mathrm{Feb}$ & 93 & $1.31 \pm 0.62^{\circ}$ & $1.58 \pm 0.99$ \\
\hline $02 \mathrm{Mar}$ & 70 & $0.11 \pm 1.11$ & $-0.43 \pm 0.86$ \\
\hline 12 & 103 & $0.62 \pm 0.55$ & $0.46 \pm 1.21$ \\
\hline 23 & 47 & $1.33 \pm 0.85$ & $1.70 \pm 0.29 \cdots$ \\
\hline $04 \mathrm{Apr}$ & 78 & $-0.06 \pm 0.20$ & $4.67 \pm 1.61^{\circ}$ \\
\hline 14 & 121 & $2.02 \pm 1.06$ & $-2.36 \pm 3.88$ \\
\hline 25 & 54 & $0.36 \pm 1.23$ & $-2.54 \pm 1.04^{\circ}$ \\
\hline 05 May & 82 & $5.39 \pm 6.00$ & $18.20 \pm 5.80^{\circ}$ \\
\hline 17 & 116 & $1.63 \pm 1.38$ & $12.70 \pm 5.32^{\circ}$ \\
\hline 28 & 64 & $0.86 \pm 0.43$ & $5.89 \pm 2.28^{*}$ \\
\hline 08 Jun & 77 & $-0.80 \pm 0.63$ & $7.06 \pm 2.18^{\cdots}$ \\
\hline 19 & 55 & $-0.66 \pm 0.99$ & $6.79 \pm 0.90^{\cdots}$ \\
\hline
\end{tabular}

cally distingushed from a zero transport $(\alpha<0.1$, ttest). Net exports were recorded for 7 flood tide phases;

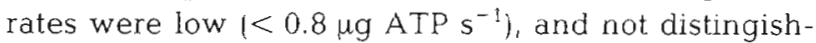
able from zero transport.

Similar results were obtained during ebb tide phases in that 27 of 33 sampling periods indicated a net import. Import rates during ebb tides were greater than during flood tides and lay between 0.46 and $18.20 \mu \mathrm{g}$ ATP $s^{-1}$. Of the ebb tide imports, $73 \%$ were statistically different from zero ( $\alpha<0.1$, t-test). Net exports of microbial biomass from the reef occurred on 6 of the 33 sampling periods. Export rates ranged from 0.18 to $2.36 \mu \mathrm{g} \mathrm{s}^{-1}$ with none statistically different from zero.

In summary, the mass transport of microbial biomass was determined for 66 periods of water flow over the reef community. A net import of microbial biomass to the reef occurred on 53 of $66(82 \%)$ sampling periods and $52 \%$ of import rates were significantly different from zero. There were only 13 periods during which microbial biomass was exported from the reef and no export rate could be statistically distingushed from a net zero transport.

\section{Annual cycle and budget}

The seasonal distribution of average net instantaneous transports of microbial biomass during flood and ebb tide phases are shown in Fig. 5. Peak transport actvity occurred during the period covering spring through early fall and corresponded to the period of peak planktonic microbial biomass levels (Chrzanowski unpubl. data) and the period of peak filter-feeder metabolism. The seasonal signature was more pronounced during ebb tides than during flood tides. Some uptake took place during the winter season but rates were low compared to rates during warmer seasons.

Data in Fig. 5 were used to construct a regression model that would permit the estimation of the net flux for a given month. A group of 38 variables were considered for inclusion in the regression model as potential 'predictor variables'. The predictor variables included various aspects of tidal conditions, rainfall conditions, freshwater flow, Spartina growth cycle, day/night conditions, wind, air temperature, and water temperature (Table 1). The variable list was subsequently refined (see 'Materials and Methods') and 4 variables were selected for use in the following models:

Flood tide model

$\mathrm{NF}=2.05 \times 10^{-5}+4.68 \times 10^{-5}(\mathrm{~L} 2 \mathrm{RAIN})-3.29 \times$
$10^{-7}(\mathrm{AWNDWT})$

Ebb tide model

$\mathrm{NF}=5.61 \times 10^{-5}-1.28 \times 10^{-4}(\mathrm{R} 1)+3.73 \times$

where NF = the estimate of net flux, and other variables are as in Table 1.

The primary purpose in building these models was to obtain the best possible estimate of annual transport rather than to judge the effects of the predictor variables. Consequently, the model giving the minimum Mallows (1973) Cp statistic was used. There were several competing models that were almost as good as those selected and the fact that a predictor variable is or is not in the model should not be taken to imply the presence or absence of an absolute cause-effect rela- 
Fig. 5. Annual distribution of average net transports through the BEST. Upper panel: flood tide phases; lower panel: ebb tide phases. Bars represent standard error of the mean, and where absent, are within the confines of the symbol

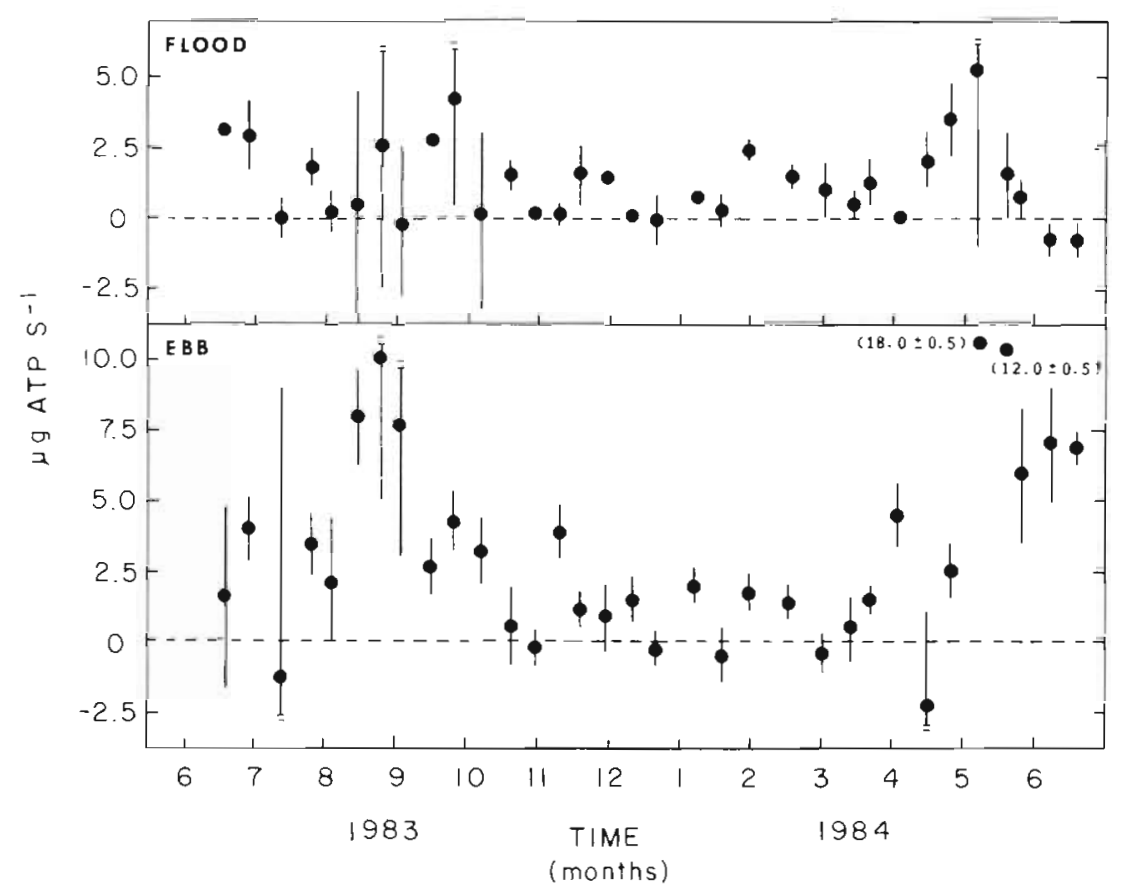

tion on transport (see Hocking 1983 for a survey of this and other model building techniques).

Monthly and annual imports of microbial biomass to the reef community are presented in Table 4 . The seasonal transport pattern, apparent in ebb-tide average-net transport data (Fig. 5) was mimicked in the monthly transport data. Monthly ebb tide transports were as much as 4 times greater than monthly flood tide transport rates. The maximum monthly transport was $5.4 \mathrm{~g}$ ATP and occurred during July-August 1983.

Considering the data on an annual basis, $16.5 \pm$ $3.2 \mathrm{~g}$ of ATP (mean $\pm \mathrm{SE}$ ) were imported to the reef during flood tides and $38.1 \pm 7.8 \mathrm{~g}$ of ATP were imported during ebb tides. The import rates for flood and ebb tides were statistically different from zero $(\alpha<0.001)$. Approximately $55 \mathrm{~g}$ of ATP were annually imported to the reef community. Assuming that the reef enclosed by the BEST is representative of reef communities throughout the North Inlet, then ATP was imported to reef communities at a rate of $7 \mathrm{~g} \mathrm{~m}^{-2} \mathrm{yr}^{-1}$.

Populations of filter-feeding organisms within salt marsh environments have the potential to filter volumes of water equal to the tidal prism (Dame et al. 1980, Jordan 1980). High filtering rates and the ability to remove small particles implicate filter feeders as major components in the flux of carbon between benthic and water column systems (Dame et al. 1980 , Wright et al. 1982). To assess the flow of microbial biomass relative to total carbon flow through the ecosystem, the ATP flux rate was converted to a carbon flux by using the conversion factor of 250:1 (C:ATP, see Karl 1980, p. $764-766$ for a complete discussion of the validity and assumptions inherent in such a conversion). The resultant ATP-C flux was equivalent to $1750 \mathrm{~g} \mathrm{C} \mathrm{m}^{-2} \mathrm{yr}^{-1}$. This rate, when converted to a net instantaneous rate, equals $55 \mu \mathrm{g} \mathrm{C} \mathrm{m} \mathrm{C}^{-2} \mathrm{~s}^{-1}$ or $435 \mu \mathrm{g} \mathrm{C}$ $s^{-1}$ for the reef area enclosed by the BEST.

Given that the transport rate is representative of the reef community, it is necessary to ask if the import rate could be accounted for by planktonic microbial biomass loads. The primary contributors to the ATP measure are phytoplankton and bacterioplankton

Table 4. Monthly and annual net transports of ATP through the BEST

\begin{tabular}{|c|c|c|c|}
\hline \multirow{2}{*}{$\begin{array}{l}\text { Dates } \\
(1983-1984)\end{array}$} & \multirow{2}{*}{$\begin{array}{l}\text { Number of } \\
\text { tidal cycles }\end{array}$} & \multicolumn{2}{|c|}{ Total ATP transport $(\mathrm{g})$} \\
\hline & & Flood tides & Ebb tides \\
\hline 19 Jun - 18 Jul & 58 & 1.2 & 5.2 \\
\hline $19 \mathrm{Jul}-18$ Aug & 60 & 1.2 & 5.4 \\
\hline 19 Aug - 18 Sep & 60 & 1.7 & 5.0 \\
\hline $19 \mathrm{Sep}-18 \mathrm{Oct}$ & 58 & 1.3 & 3.9 \\
\hline $19 \mathrm{Oct}-18 \mathrm{Nov}$ & 59 & 1.3 & 2.8 \\
\hline 19 Nov - 18 Dec & 58 & 1.3 & 2.1 \\
\hline $19 \mathrm{Dec}-18 \mathrm{Jan}$ & 60 & 1.2 & 0.7 \\
\hline $19 \mathrm{Jan}-18$ Feb & 60 & 1.2 & 1.0 \\
\hline $19 \mathrm{Feb}-18 \mathrm{Mar}$ & 56 & 1.5 & 1.6 \\
\hline $19 \mathrm{Mar}-18 \mathrm{Apr}$ & 60 & 1.6 & 2.4 \\
\hline 19 Apr - 18 May & 58 & 1.5 & 3.3 \\
\hline 19 May - 18 Jun & 60 & 1.4 & 4.7 \\
\hline Annual summary & 707 & $16.5 \pm 3.3^{\circ}$ & $38.1 \pm 7.8^{\circ}$ \\
\hline$\cdot=\operatorname{mean} \pm \mathrm{SE}$ & & & \\
\hline
\end{tabular}


(pumping samples tends to exclude other organisms). Wright et al. (1982) estimated summer bacterial biomass levels to be $112 \mu \mathrm{g} \mathrm{C}^{-1}$ for the Essex Estuary (Massachusetts, USA) while Rublee et al. (1983) estimated a somewhat lower level of approximately $80 \mu \mathrm{g}$ $\mathrm{C}^{-1}$ for the Rhode River Estuary, Maryland, USA. Assuming an intermediate annual level for the milder conditions typical of the North Inlet, ATP originating solely from bacteria, and a $100 \%$ removal efficiency by the reef community, a water flow of only $4.5 \mathrm{l} \mathrm{s}^{-1}$ would be required to account for the net import $(100 \mu \mathrm{g}$ $\left.\mathrm{C}^{-1} \times 4.5 \mathrm{l} \mathrm{s}^{-1}=450 \mu \mathrm{g} \mathrm{C} \mathrm{s}{ }^{-1}\right)$. Average discharge rates through the BEST were approximately $18 \mathrm{l} \mathrm{s}^{-1}$.

Phytoplankton biomass in the North Inlet averages approximately $240 \mu \mathrm{g} \mathrm{C}{ }^{-1}$ (Chrzanowski \& Zingmark 1986, Zingmark unpubl. data) and the phytoplankton represent a major component of the ATP measure. In this study, $55 \%$ of the total microbial carbon imported to the reef originated with the phytoplankton (based on ATP-C to chlorophyll $a-C$ comparison and assuming a 30:1 C:chlorophyll a conversion factor: Strickland 1960). Consequently, if only the bacterioplankton and phytoplankton were accounted for, the biomass associated with a $1.31 \mathrm{~s}^{-1}$ water flow rate could account for

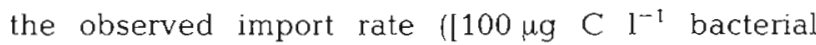
biomass $+240 \mu \mathrm{g} \mathrm{C} \mathrm{l}^{-1}$ phytoplankton biomass] $\times$ $1.3 \mathrm{I} \mathrm{s}^{-1}=442 \mu \mathrm{g} \mathrm{C} \mathrm{s}^{-1}$ ). The actual removal efficiency of the reef was estimated to be $20 \%$ : ([average ATP concentration at input - average ATP concentration at output]/average ATP concentration at input) $\times 100$. At this efficiency a flow rate of only $7 \mathrm{l} \mathrm{s}^{-1}$ would be necessary to meet the biomass demand. Thus, even when both of the above situations are considered, there was 2.6 to 14 times more microbial biomass flowing through the BEST (on a net basis) than were needed to account for the observed uptake by the reef community.

In conclusion, the reef community appears to have a considerable impact upon suspended microbial populations and consequently on carbon flow in general. Processing of microbial carbon by the reef community represents one of many routes of intra-ecosystem processing, while carbon flow between the North Inlet and the ocean represents a cumulative inter-ecosystem flow. A comparison of the intra-system microbial carbon flow $\left(1750 \mathrm{~g} \mathrm{C} \mathrm{m}^{-2} \mathrm{yr}^{-1}\right)$ to inter-system particulate organic carbon flow $\left(87 \mathrm{~g} \mathrm{C} \mathrm{m}^{-2} \mathrm{yr}^{-1}\right.$; Chrzanowski et al. $1982 \mathrm{~b}$ ) reveals that the net flow of microbial carbon into reef communities was 20 times greater than the net flow of particulate organic carbon from the entire marsh system to the ocean.

Acknowledgements. These data were collected with the help of an interdisciplinary research group supported by NSF grant DEB 8119752 . Special thanks to Steven B. Knoche and Elizabeth Haskins for their technical assistance.

\section{LITERATURE CITED}

Birkbeck, T. H., McHenery, J. G. (1982). Degradation of bacteria by Mytilus edulis. Mar. Biol. 72: 7-15

Chrzanowski, T. H. Stevenson, L. H., Kjerfve, B. (1981). Variability in total microbial biomass measurements made in cross-sections of salt-marsh creeks. Mar. Geol. 40: 155-170

Chrzanowski, I H., Stevenson, L. H., Spurrier, J. D. (1982a). Transport of microbial biomass through the North Inlet ecosystem. Microb. Ecol. 8: 139-156

Chrzanowski, T H., Stevenson, L. H., Spurrier, J. D. (1982b). Transport of particulate organic carbon through the North Inlet ecosystem. Mar. Ecol. Prog. Series 7: 231-245

Chrzanowski, T. H., Zingmark, R. G. (1986). Passive filtering of microbial biomass by Spartina alterniflora. Estuar. coast. Shelf Sci (in press)

Cochran, W. G. (1977). Sampling techniques. Wiley, New York

Dame, R. F. (1976). Energy flow in an intertidal oyster population. Estuar. coast. mar. Sci. 4: 243-253

Dame, R. F. (1979). The abundance, diversity and biomass of macrobenthos on North Inlet, South Carolina, intertidal oyster reefs. Proc. natn. Shellfish. Ass. 69: 6-10

Dame, R., Zingmark, R., Stevenson, L. H., Nelson, D. (1980). Filter feeder coupling between the estuarine water column and benthic subsystems. In: Kennedy, V.S. (ed.) Estuarine perspectives. Academic Press, New York, p. $521-527$

Dame, R. F., Zingmark, R., Haskins, E. (1984). Oyster reefs as processors of estuarine materials. J. exp. mar. Biol. Ecol. 83: $239-247$

Erkenbrecher, C. W., Stevenson, L. H. (1975). The influence of tidal flux on microbial biomass in salt marsh creeks. Limnol. Oceanogr. 20: 618-625

Gardner, L. R., Bohn, M. (1980). Geomorphic and hydraulic evolution of tidal creeks on a subsiding beach ridge plain, North Inlet, S. C. Mar. Geol. 34: 91-97

Hocking, R. R. (1983). Developments in linear regression methodology: 1959-1982. Technometrics 25: 219-230

Holm-Hansen, O. (1973). Determination of total microbial biomass by measurement of adenosine triphosphate. In: Stevenson, L. H. Colwell, R. R. (ed.) Estuarine microbial ecology. Univ. of S. Carolina Press, Columbia, p. 73-89

Holm-Hansen, O., Booth, C. R. (1966). The measurement of adenosine triphosphate in the ocean and its ecological significance. Limnol. Oceanogr. 11: 510-519

Jordan, T E. (1980). A nitrogen budget of the ribbed mussel, Geukensia demissa, and its significance in nitrogen flow in a New England salt marsh. Ph. D. thesis, Boston Univ.

Karl, D. M. (1980). Cellular nucleotide measurements and applications in microbial ecology. Microbiol. Rev. 44 739-796

Mallows, C. L. (1973). Some comments on Cp. Technometrics 16: $661-675$

McHenery, J. G., Birkbeck, T H. (1985). Uptake and processing of cultured microorganisms by bivalves. J. exp. Mar Biol. Ecol. 90: 145-164

Nixon, S. W (1981). Between coastal marshes and coasta] waters - a review of twenty years of speculation and research on the role of salt marshes in estuarine productivity and water chemistry. In: Hamilton, R., McDonald, K. B. (ed.) Estuarine and wetland processes with emphasis on modeling. Plenum, New York, p. 437-526

Reimold, R. J. (1972). The movement of phosphorus through the salt marsh cord grass Spartina alterniflora Loisel. Limnol. Oceanogr. 17: 606-611 
Rublee, P. A., Merkel, S. M., Faust, M. A. (1983). Nutrient flux in the Rhode River: Tidal transport of microorganisms in brackish marshes. Estuar. coast. Shelf Sci. 17: 669-680

SAS Institute Inc. (1985). SAS User's guide: Statistics, version 5 edition. SAS Institute, N. Carolina

Stevenson, L. H., T. H. Chrzanowski, Erkenbrecher, C. W (1979). The adenosine triphosphate assay: Conceptions and misconceptions. In: Costerton, J. W., Colwell, R. R. (ed.) Native aquatic bacteria: Enumeration, activity and ecology. ASTM STP 695, American Society for Testing and Materials, Maryland, p. 99-116

Stevenson, L. H., Wilson, C. A., Chrzanowski, T. H. (1981).
The assay of adenosine 5'-triphosphate extracted from salt-marsh microbiota. Can. J. Microbiol. 27: 633-635

Strickland, J. D. (1960). Measuring the production of marine phytoplankton. Bull. Fish. Res. Bd Can. 122

Wilson, C. A., Stevenson, L. H., Chrzanowski, T H. (1981). The contribution of bacteria to the total adenosine triphosphate extracted from the microbiota in the water of a saltmarsh creek. J. exp. mar Biol. Ecol. 50: 183-195

Wright, R. T., Coffin, R. B., Ersing, C. P., Pearson, D. (1982). Field and laboratory measurements of bivalve filtration of natural marine bacterioplankton. Limnol. Oceanogr. 27 : $91-98$

This article was submitted to the editor; it was accepted for printing on February 11, 1986 